\title{
Samhällets lidandeproduktion och behov av resiliens
}

Av Jan Beskow

Länge har människan noterat att tusentals människor dör därför att det samhälle vi byggt i rekordfart de senaste 250 åren inte är anpassat till hur vi är konstruerade. Inom olycksfallsprevention kom de goda resultaten först när individperspektivet övergavs för systemperspektivet. Principerna för olycksfallsprevention är en grundbult i byggandet av framtida fysiska samhällen. Ett viktigt faktum försummade man dock. Det dör lika många av brister i samhällets psykosociala konstruktion!

Suicidprevention är fortfarande individinriktad och ineffektiv. Ett systemteoretiskt perspektiv med resiliens som mål, dvs. snabb återhämtning under fortsatt utveckling, borde kunna ändra på detta. I fortsättningen bör samhället psykosocialt utformas enligt suicidpreventiva principer för att reducera antalet dödsfall och skador och bättre anpassas till vad vi klarar av.

\section{Samhällets lidandeproduktion och behov av resiliens}

Suicidala personer och deras anhöriga lider svårt av suicidalitet. Samhället representerat av personal inom hälso- och sjukvården lider av att inte kunna möta och hjälpa dem effektivt. Allt detta ingår i samhällets produktion av lidande. Vi behöver förstå vad som händer för att samhället skall kunna utvecklas vidare. Ett nytt grepp är nödvändigt.

\section{En häpnadsväckande okänslighet}

I arbetet med suicidprevention har jag mött en ung kvinna som utsattes för en ovanligt rå gruppvåldtäkt av tre unga män. För henne var detta en psykisk olyckshändelse. Denna första fysiska våldtäkt hade hon med rätt vård sannolikt klarat av på några månader. På den följde en andra våldtäkt, som var mycket värre. Genom samhällets tabuering och genom vår tendens att på olika sätt straffa våldtäktsoffer fick hon ingen akut vård utan slöt sig inom sig själv. Detta berövade henne mer än tio år av hennes liv.

De tre männens beteende väckte min uppriktiga vrede. Är de egentligen människor, när de gör så? Medan det samhälle som svarade för den andra våldtäkten, som var mycket värre, hos mig knappast föranledde någon vrede alls, snarare ett tyst accepterande: "Ja, så är det!" Nu med lite distans lär det mig att ett individperspektiv på människors lidande leder till en demonisering av förövaren till tröst för mig själv, men också till en brist på engagemang i och ansvarstagande för samhällets produktion av lidande. "Samhället" är en kognitiv konstruktion. Samhället lider inte. Det är den enskilde medlemmen av kött och blod som lider. Därför måste var och en av oss efter bästa förmåga använda sitt lidande till att ta ansvar för och ständigt förbättra samhället.
En del skadas så svårt att de dör psykiskt eller nästan dör och därför allvarligt överväger att döda sig själva. Låt oss försöka förstå hur det blivit så här samt ge det en teoretisk ram med hjälp av begreppen systemteori och resiliens (=återhämtning).

\section{Det nya samhället}

Homo sapiens sapiens har skapat ett aldrig tidigare skådat samhälle, fantastiskt, underbart, men inte helt anpassat efter hur vi själva är konstruerade. Under årmiljoner har informationsöverföringen varit väsentligen biologisk, buren av gener.

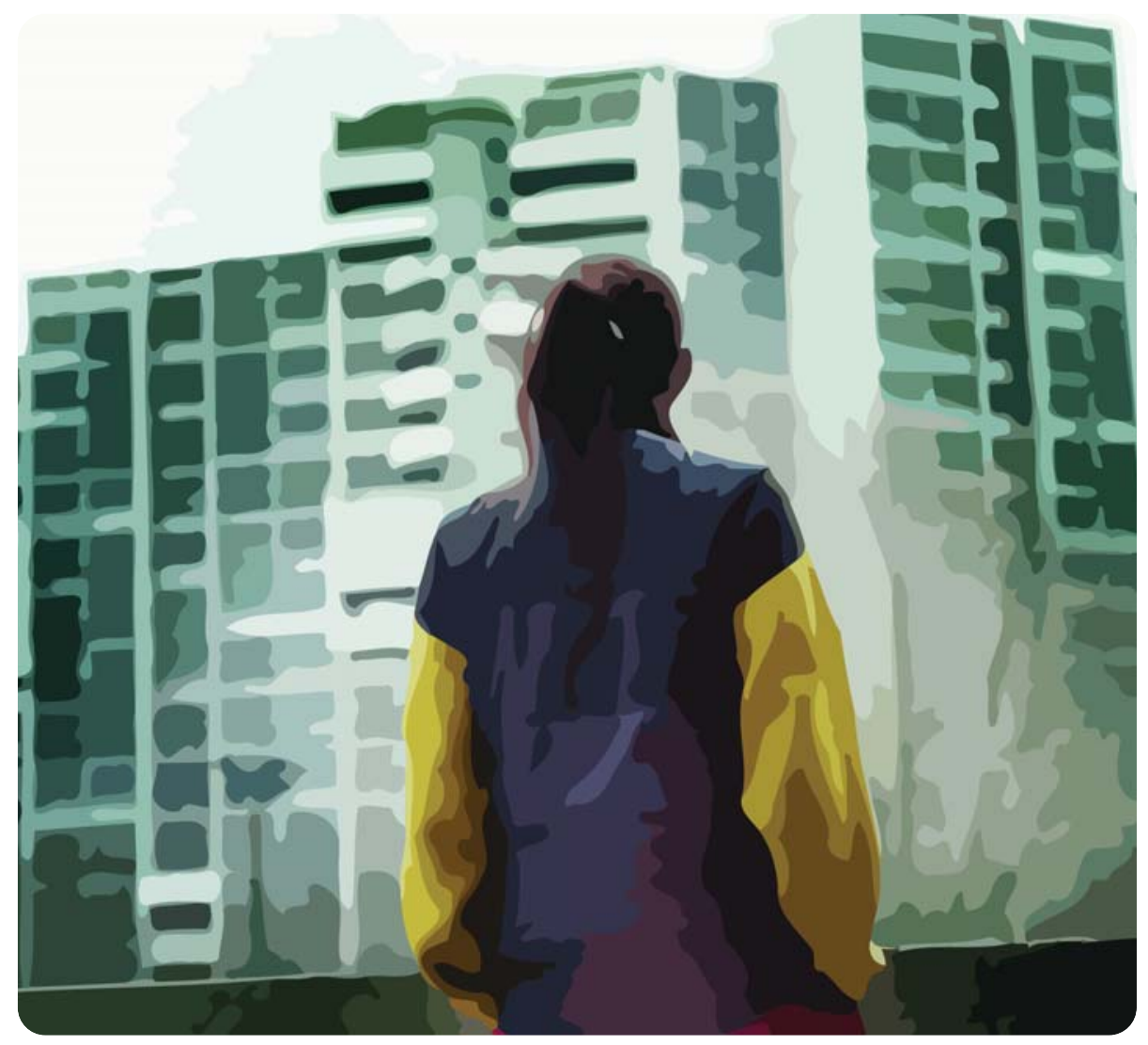


Utvecklingen har varit mjuk och relativt långsam under ständiga avvägningar mot miljön. De bäst anpassade har överlevt och fört sina gener vidare - "survival of the fittest".

Sedan några hundra år leds utvecklingen i stället av människans framhjärna med dess kognitioner (varseblivningar, bilder, föreställningar, minnen, tankar och planer), som förs vidare genom minnesgener, memer. Det är snabba förändringar, som lett till stora ingrepp i jordens ekologi. Människan har nu kapacitet att förstöra livet på jorden och är också på god väg att göra det. Enda möjligheten är att ytterligare utveckla våra kognitioner och vår medvetenhet. I det gigantiska systemet människa/globen måste allt inkluderas och så långt möjligt förstås och hanteras. Först långsamt har det gått upp för oss att detta samhälle förutom sina värdefulla produkter också kontinuerligt producerar lidande, både fysiskt och psykosocialt.

\section{Var finns hoten?}

I årmiljoner har människor utsatts för ständiga hot utifrån, utanför människan själv: Köld och hetta, svält och infektioner, hot från fientliga djur och människostammar samt från naturkatastrofer. Och var det några inom gruppen som inte passade in, så exkluderade man och demoniserade dem, gjorde dem till yttre fiender. Småningom märkte man emellertid samhällets fysiska brister.

Fysiska olycksfall. Man märkte att folk dog i tusental av brister i samhällets fysiska konstruktion. De dog på vägarna och i industrierna. I enlighet med det inlärda mönstret tänkte man sig att orsakerna till hot och olyckor låg utanför människor och människors ansvar. Det var öde eller slump, inget vi kunde göra något åt.

Detta undvikande sänkte dock inte antalet olyckor. I stället började man lägga orsakerna hos enskilda människor, olycksfåglar. Inte heller det gav särskilt bra resultat. För bara 40 år sedan - ett ögonblick av årmiljonerna - insåg man att de snabba förlopp som föregick en olycka inte bara utspelade sig inne i utan framför allt

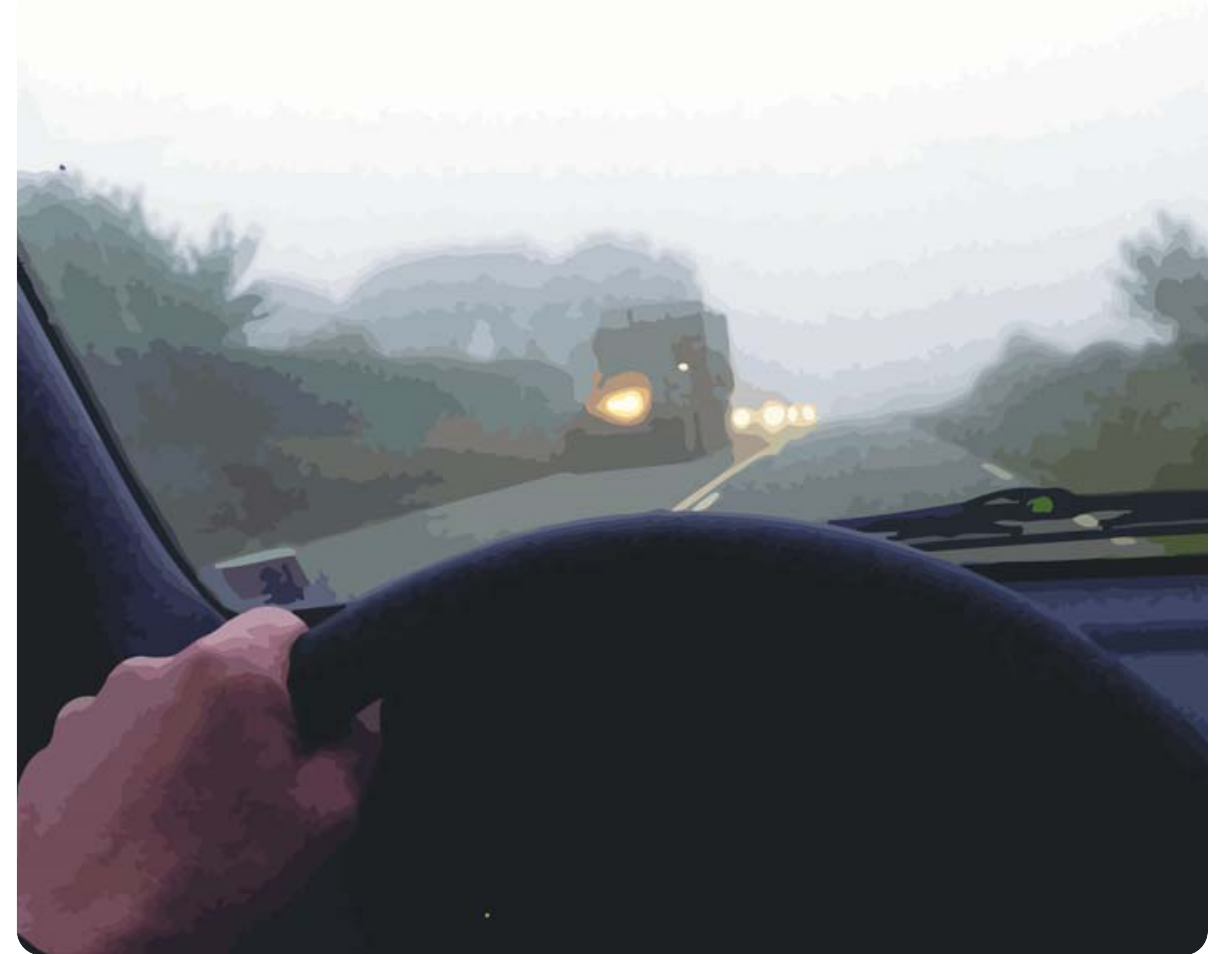

mellan enskilda människor, eller mellan människor och fysiska faktorer. Väsentligen handlade det om kommunikation, i trafiken t ex om snabba interaktioner mellan förare, fordon och trafikmiljö. Systemperspektivet beskrev samspelet mellan system på olika nivåer genom snabba kommunikativa förlopp med feedback. Dessa teoretiska framsteg gjorde att man började förstå vad det handlade om. Sedan dess arbetar olycksfallspreventionen genom att förbättra såväl förare, som bilar och omgivande miljö samt framför allt samspelet mellan dem. När samhället formas tar man också stor hänsyn till preventiva principer för att i framtiden ytterligare reducera antalet skador av fysiska orsaker. Från att ha legat utanför det naturliga mänskliga systemet ligger nu de dödliga hoten till stor del inom det av människan skapade psykosociala systemet eller mellan dess olika subsystem.

Psykiska olycksfall. Försöken inom hälsooch sjukvården att förstå suicidalitet har genomlöpt de två första av dessa faser. Även här började man från början. Suicid berodde på öde eller slump, inget vi kan göra något åt. Många tror så fortfarande. Lärdomen av ödesförklaringar är att det finns en stor mängd orsaker bakom en suicidhandling, varav vi bara kan se, förstå och hantera ett fåtal.

Med stöd av den psykiatriska sjukdomsmodellen landade man sedan $\mathrm{i}$ individperspektivet. Orsakerna låg inom människan, det synsätt som fortfarande dominerar. Det innebär att vissa sårbara personer får en psykisk sjukdom, särskilt depressioner, och måste behandlas för denna. SSRIpreparat blev förstahandsval. Detta var ett framsteg eftersom orsakerna i princip sågs som åtgärdbara. Diagnostik och behandling av psykisk sjukdom är och förblir en grundsten inom suicidprevention. Men teoretiskt var framsteget ofullständigt. Den psykiatriska sjukdomsmodellen är en modell för psykisk sjukdom, men inte för suicidalitet. Genom sin tendens till monokausalitet fångar modellen inte heller komplexiteten bakom suicidaliteten. Individperspektivet blockerar en djupare förståelse. "Samhället" avsade sig allt ansvar. Kanske är det nu dags att ta nästa steg? 
Fråga sig om suicid kan vara en följd av brister i samhällets psykosociala konstruktion, som ger upphov till psykiska olycksfall, händelser orsakade av en komplicerad väv av orsaksfaktorer av vilka vi bara kan kontrollera ett fåtal. För att undersöka detta är det klokt att börja på en konkret och detaljerad nivå.

\section{Olycksfallsperspektiv}

Kan man verkligen se suicid som olycksfall? Tanken styrs av orden, inte minst av våra vedertagna definitioner. Suicid definieras som "en medveten, uppsåtlig, självförvållad, livshotande handling som leder till döden" (min kursivering). En olyckshändelse däremot är varken medveten eller uppsåtlig, det är något som bara händer, som ingen rår för. Då kan väl suicid inte vara olyckshändelse?

Bilföraren och förloraren. När jag i början av 1980-talet funderade över dessa frågor började jag med att analysera ett dödsfall i trafiken. Det var en medelålders "bilförare", som en dag med snö och halka körde bil trots att bilens bromsar och han själv var i dålig kondition. Han dog i ett möte med en långtradare, som i en skarp kurva delvis hade kommit över på bilförarens sida av vägen. Detta jämfördes med en 20-årig "förlorare", en man som förlorat sin flickvän, hamnat i en kris som djupnade till en depression. När han varje fredag drack alkohol blev suicidaliteten medveten. Han hängde sig efter en obetydlig ytterligare provokation. För detaljer se Beskow 2010.

Resultatet blev att det i båda fallen fanns många påverkande faktorer, delvis slumpvis uppträdande. Dessutom fattade var och en av dem minst tre beslut som aktivt ökade risken att dö. Trots detta har vi goda skäl att tro att varken "bilföraren" eller "förloraren" ville dö, förutom att den senare under sina sista minuter gav upp kampen mot de påträngande suicidtankarna. Man kan t.o.m tänka sig att "bilförarens" ansträngningar att klara av situationen också blev så kaotiska att han till sist gav upp försöken att rädda sig, bara lät det ske.
Tvärtom kämpade de intensivt med sina kognitioner för att hitta en utväg och rädda livet, dock utan att lyckas. För "bilföraren" gick den akuta processen fortare, kanske på någon minut, jämfört med "förlorarens" fem till tio minuter. Den senare hade också kämpat i flera veckor för att försöka övervinna sina påträngande suicidala impulser. Samtidigt hade han utvecklat en färdig suicidal plan, som aktiverades av en ytterligare påfrestning, som blev den utlösande triggern.

Udda situationer med höga krav. Enligt Hollnagel är en olyckshändelse "ett plötsligt och oförutsett inträffat trauma som ger icke önskade effekter." Definitionen stämmer på dem båda. Detta leder fram till följande definition:

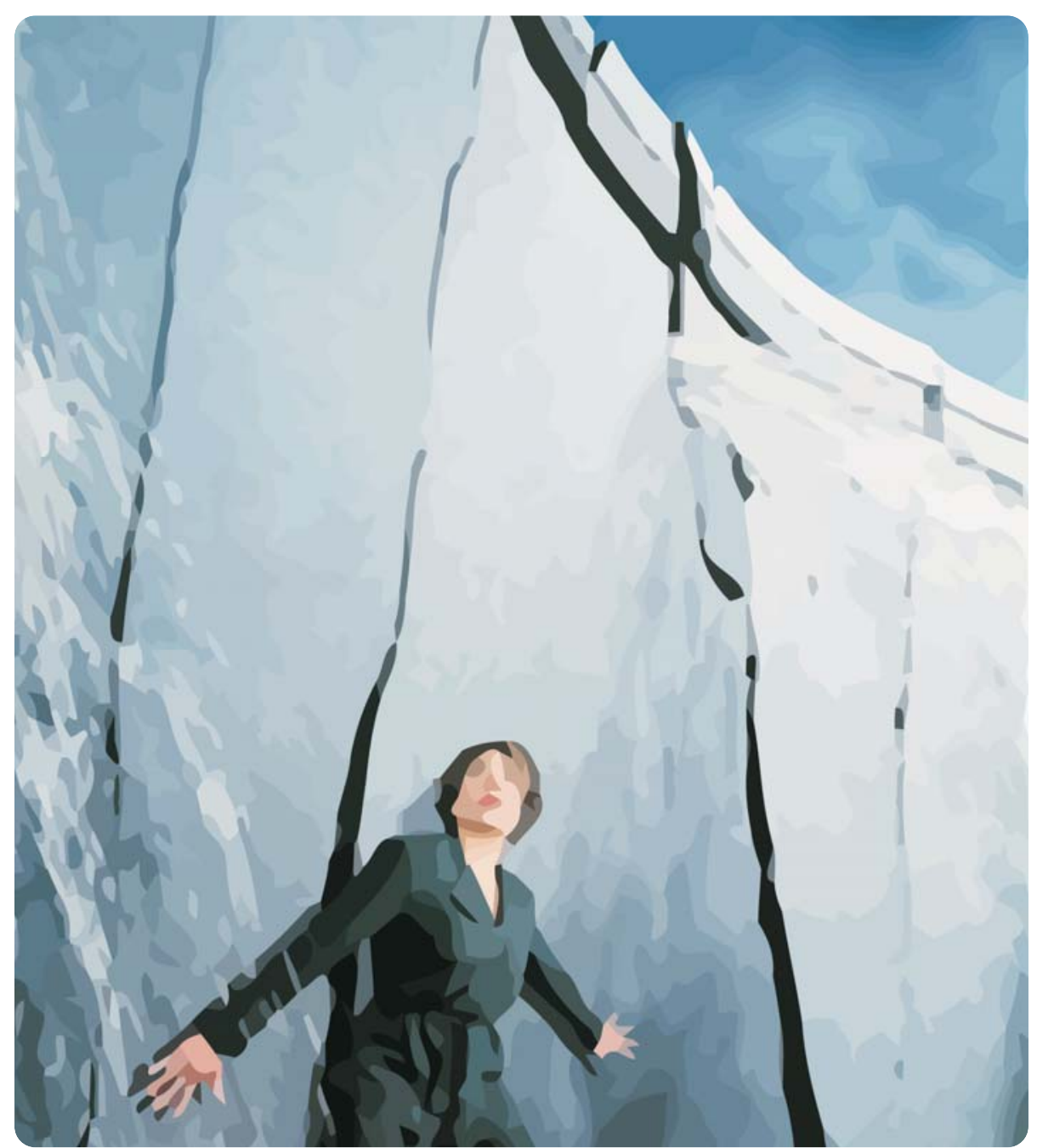

En olyckshändelse är en kognitiv insuffciens av problemlösningsförmågan i en specifik, ovanlig och extremt krävande situation. Denna kan uppstå när en person blir så överväldigad av starka, snabbt påkommande fysiska krafter, så att hon inte hinner hantera dem, en fysisk olyckshändelse, eller när hon blir så överväldigad av starka, snabbt påkommande psykiska krafter att hon inte hinner hantera dem, en psykisk olyckshändelse.

Förebyggande arbete. Omhändertagandet av suicidala personer har fokuserat på att förhindra det slutliga självmordet. Detta är naturligt, man vill i första hand förebygga dödsfall. Proportionen mellan antalet personer med allvarliga suicidtankar, suicidförsök och suicid är ungefär 100:10:1. 
Att då lägga allt krut på att förebygga detta enda suicid och försumma de övriga 99 är minst sagt att vara sent ute. Förebyggande arbete måste börja tidigt. Detta leder fram till följande definition:

Suicidalitet är att tänka på, planera och genomföra ett suicidförsök eller ett suicid. Det är en fantiserad eller genomförd flykt av en människa som är så svårt plågad av livet att hon inte längre orkar bära det.

\section{Modeller för att förstå olyckor}

Linjära modeller. Olycksfallsforskarna förstod att olyckor uppstår ur en oerhört komplex väv av händelser. För att analysera dessa förlopp har de använt såväl enkla lineära modeller som mer komplicerade epidemiologiska modeller med riskfaktorer av olika tyngd, d v s ungefär där psykiatrisk forskning står i dag. En mer komplicerad lineär modell beskriver små brister på flera olika nivåer av en organisation. När dessa råkar sammanfalla kan en olyckshändelse inträffa. Inte så att bristerna åstadkommer olyckan men gör det möjligt att den sker. I dessa system räknar man fortfarande med tämligen fasta strukturer. Att omöjliggöra olyckshändelser genom barriärer, $t$ ex mitträcken är en av många åtgärder. Dessa exemplierar också utvecklingen från retroaktiva till pro-aktiva insatser, d v s man försöker inte bara begränsa skadeverkningarna av en olycka. Man försöker också räkna ut var liknande olyckor kan inträffa och konstruera samhället så att de inte inträffar.

Systemisk modell. Övergången till ickelineära eller systemiska modeller innebär ett nytt sätt att se. Här handlar det om stora komplexa system med näst intill oändligt antal inblandade faktorer i ständig rörelse. Mer adekvat är därför att tala om funktioner, som kommunicerar med varandra, t.ex en kognitiv funktion fokuserad på frågan om och i så fall hur jag kan/ bör bromsa, som kommunicerar med bromsarnas funktion men också tar hänsyn till vägbanans beskaffenhet. Subsystem i människor, mekanik och natur binds samman, inkluderas i övergripande system. Det handlar nu inte längre bara om vad en enskild person gör eller inte gör utan hur hennes eget system och dess funktioner kommunicerar och interagerar med andra system och deras funktioner. Samtliga kan påverkas av såväl långvarigt som kortvarigt verkande faktorer. Skador uppkommer genom att många funktioner under kort tid snabbt interagerar med varandra och ibland okontrollerat spränger hela systemets toleransgränser (Rasmussen, 2006). En olyckshändelse blir inte en onormal och obegriplig avvikelse $i$ ett perfekt system utan ett normalt fenomen i ett mänskligt och därmed ofullkomligt system.

\section{Framtida suicidprevention}

Systemisk. Varje person är del av många system (familj, arbete $\mathrm{mm}$ ) och har många subsystem (rörelseapparat, hjärna, språksystem $\mathrm{mm}$ ). Vårt inre liv är ett oändligt snabbt flöde av tankar, bilder, minnen, känslor, kroppsförnimmelser $\mathrm{mm}, \mathrm{d}$ v $\mathrm{s}$ av små informationsbitar. Det samhälle vi byggt runt omkring oss är också komplicerat och består av en oändlig mängd detaljer och flöden av många små informationsbitar. Systemteori handlar om samspelet mellan dessa. Det handlar om stimuli och responser med feedback.

Informationsbitar är instabila och lätta att förändra, vilket kan vara både positivt och negativt. Enskilda fasta kroppar, substanser, personer, är däremot stabila och svåra att förändra. Flödena är snabba med höga krav på träffsäkerhet. Svarsreaktionerna skall därför inte bara vara automatiska utan ge optimalt anpassad feed-back. Det är detta som håller systemen samman.

Ett mellanmänskligt exempel är när modern försöker finna det precisa uttrycket både i sina ögon, sin röst och sina händer för att få kontakt med sitt barn och tolka dess uttryck. Så bygger hon upp en bärande relation som gör en precis kommunikation möjlig i ett visst ögonblick, på en specifik plats, i en specifik situation. Sådan precis kommunikation tränger djupt in och har stor förändrings-

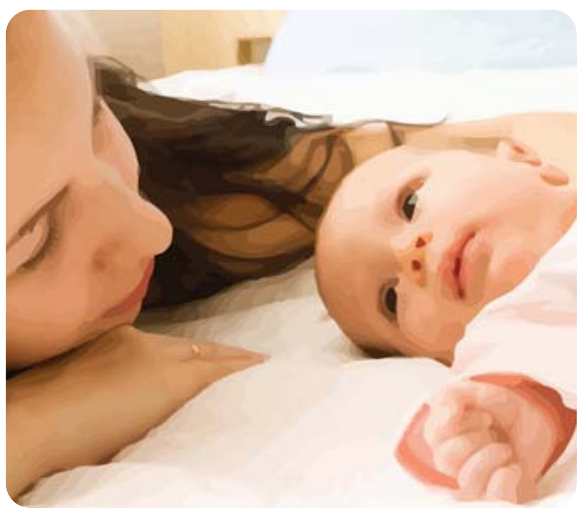

kraft. Så stärks relationer mellan olika system och nya byggs.

Här finns också en etisk dimension.

Fokus på personer innebär att ett felsteg är hela personens fel. "Det är du som är problemet!" Utstötningen, inlärd under årmiljoner, ligger nära till hands. Den genererar onödig skuld, skam och i förlängningen även suicidalitet. System- och olycksfallsperspektivet är barmhärtigare.

Resiliens. Resiliens är en öppen målbeskrivning för att utveckla suicidprevention inom personer och organisationer utifrån ett systemteoretiskt perspektiv. Målet är inte att som nu lägga all kraft på att tränga allt djupare in i problem och svårigheter utan att i stället lägga den mesta kraften på att utveckla förmågan att klara av förändring och samtidigt ständigt vidare-utvecklas. Blicken vänds från det förgångna mot framtiden, men berikas med den smärtsamma erfarenhetens lärdomar.

Principiellt innebär detta att de aktuella systemen:

1. Värderar ett normalt, välfungerande liv högt och därför strävar efter att förverkliga det. Nu är det vanligt att man fokuserar på det som går galet. Fokus $\mathrm{i}$ resiliens är på det som går bra.

\section{Tillämpar ett ständigt lärande. I första} hand lär man sig av det som gått bra, t ex hur hotande kriser hanterats på ett bra sätt, men i andra hand också på det som gått galet, man lär av sina misslyckanden. Att observera och minnas det som gått bra ökar trygghet och utveckling. Att observera och minnas det som gått galet utvecklar systemet. 


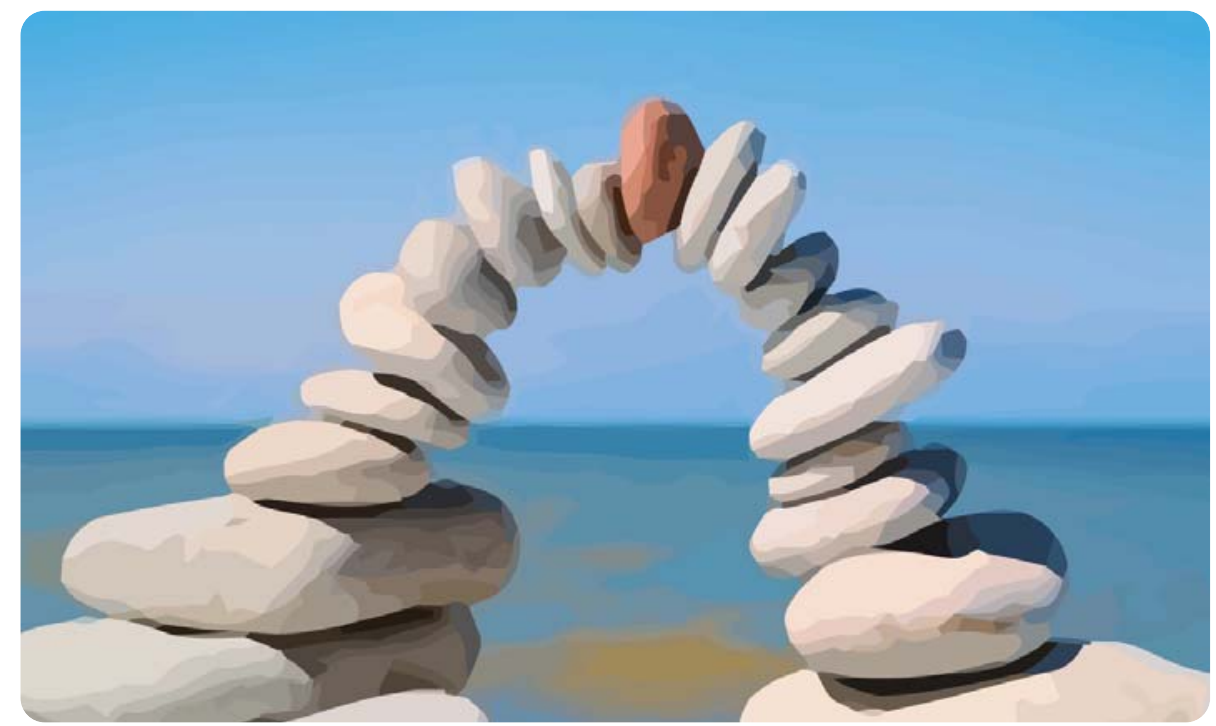

Praktiskt innebär detta en uppmaning att:

3. Träna in en känslig observans av hotande kriser så att personen respektive organisationens personal tidigt lägger märke till när sannolikheten för en negativ händelse ökar så man kan vidta effektiva åtgärder för att förhindra det; samt

\section{Att snabbt återhämta sig efter en} olyckshändelse/skada och återgå till det normala livet.

Resiliens är ett användbart mål både för organisationer och individer. Begreppet används redan inom positiv psykoterapi. På en generell och global nivå används det för att förstå komplexa social-ekologiska system och öka deras förmåga att klara av förändring och ständigt vidareutvecklas, www.stockholmresilience.org. Härmed introduceras resiliens som ett bra mål för individuell och kollektiv suicidprevention. Det innebär ett fokus på livet, levandet i stället för på döden, "av-livandet". Denna perspektivförskjutning är laddad med hopp och glädje.

\section{Konsekvenser}

Komplexiteten bakom suicidala handlingar kan bara förstås ur ett systemteoretiskt perspektiv. Suicidala personer har upplevt samhällets produktion av lidande in på sin bara kropp och djupt ner i sin själ. Deras erfarenheter har på ett smärtsamt sätt fört in döden i det kollektiva samtalet.
Samhället har reagerat med en skräckfylld kortslutning och i enlighet med en under årmiljoner utvecklad vana reagerat med exkludering, tabuering. Syftet har varit att radikalt koppla bort samhällsperspektivet ur alla orsaks- och ansvarssammanhang genom att göra suicidalitet till ett helt individuellt problem. Den suicidala personen vill ju dö. Genom att betona respekten för individualitet och mänskliga rättigheter förstärks detta ytterligare. Alla försök att hjälpa suicidala personer blir därigenom tvekluvna.

I den aktuella situationen när det mänskliga samhället hotar att utrota allt liv på jorden blir en nära upplevelse av döden en förutsättning för att realistiskt närma sig dessa problem. Den gamla metoden att hantera dödshot genom exkludering måste ersättas med en strävan efter inkludering. Suicidalitet blir en normal företeelse i bristfälliga system. Den suicidala människan är bärare av för samhällets fortsatta friska utveckling helt nödvändig information. Detta ger en tvärvändning i förståelsen av suicidalitet. Hennes djupaste strävan är inte död utan liv. Hennes kamp går inte ut på att mörda sig själv utan på att till nästan varje pris försöka stanna kvar inom det/de system hon tillhör. Att till nästan varje pris överleva. Att vägra mörda sig själv. (Se artikel i Psykisk hälsa, 2012:2, årgång 53 och Suicidologi 2013, nr. 3)

\section{Radikal effektivsering av suicid- prevention}

Orsaker till hot och olyckor har evolutionärt förlagts utanför människan, sedan inne i människan och nu till sist mellan människan och hennes fysiska och psykiska omgivning. I systemteorin ligger fokus på snabb kommunikation inom och mellan hierarkiskt ordnade system. Även mycket snabba skeenden kan analyseras på detta sätt. När olyckor händer är målet resiliens, dvs. att så snabbt som möjligt återgå till det normala. Detta synsätt har varit och är framgångsrikt inom olycksfallspreventionen. Liknande perspektiv skulle sannolikt radikalt effektivisera suicidpreventionen. Systemteorin är användbar både på organisationer, mekaniska föremål och människor. Börja redan nu träna dig i att se dig själv och din omgivning som ett antal snabbt interagerande system!

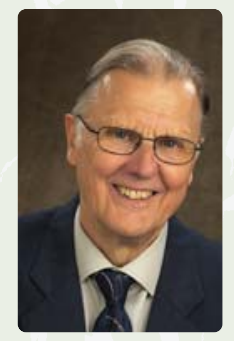

Jan Beskow är professor och läkare, specialist i psykiatri och socialmedicin. Han är f.d.ordf i Suicidprevention i Väst, SPIV, och knuten till Sektionen för psykiatri, Sahlgrenska Akademin i Göteborg. Beskow har arbetat 45 år med suicidprevention.

\section{Lästips}

Beskow J. The meaning of suicidality (2010). Kapitel 2 i Osorno J, Svanström L, Beskow J. Community Suicide Prevention. Stockholm: Karolinska institutet. Kan laddas ner gratis från www.ki.se/csp/pdf/Publications/suicide prevention 2nd.pdf - Redogör mer detaljerat för olycksfallsperspektivet inom suicidpreventionen.

Beskow J. Peter Pronovosts moraliska val. Orsakerna ligger inte utanför, inte inne i oss utan mellan oss (2011). Läkartidningen; (108)51: 2693. Handlar om betydelsen av att ta ett personligt ansvar för de system man är engagerad i.

Hollnagel E. Barriers and Accident Prevention (2004). Ashgate, Burlington. Framväxten av en teoretiskt grundad olycksfallsprevention.

Hollnagel E. The ETTO-principle. Efficiency-Thoroughness Trade-Off (2009). Farnham: Ashgate. Om den nödvändiga balansen mellan effektivitet och noggrannhet.

Rasmussen J, Svedung I. Proactive Risk Management in a Dynamic Society. Swedish Rescue Services Agency, National Center for Learning from Incidents and Accidents, NCO 2006:7. Olycksfallsprevention: teori med praktiska exempel.

Öqvist 0. Systemteori i praktiken. Konsten att lösa problem och nå resultat (2008). Stockholm: Gothia Förlag. Introduktion till systemteori.

Artikkelen er tidligere publisert i Psykisk hälsa, 2012:2, årgang 53. 